University of Nebraska - Lincoln

DigitalCommons@University of Nebraska - Lincoln

Library Philosophy and Practice (e-journal)

Libraries at University of Nebraska-Lincoln

Fall 3-12-2021

\title{
Changes in Teaching and Learning in Higher Education during Covid-19 Lockdown: A Study of LIS Students in India
}

Sana Aslam

Babasaheb Bhimrao Ambedkar University, sanaaslam13895@gmail.com

Sharad Kumar Sonkar

Babasaheb Bhimrao Ambedkar University, sksonker@yahoo.co.in

Valentine Joseph Owan

University of Calabar, owanvalentine@gmail.com

Follow this and additional works at: https://digitalcommons.unl.edu/libphilprac

Part of the Library and Information Science Commons

Aslam, Sana; Sonkar, Sharad Kumar; and Owan, Valentine Joseph, "Changes in Teaching and Learning in Higher Education during Covid-19 Lockdown: A Study of LIS Students in India" (2021). Library Philosophy and Practice (e-journal). 5223.

https://digitalcommons.unl.edu/libphilprac/5223 


\title{
Changes in Teaching and Learning in Higher Education during Covid-19 Lockdown: A Study of LIS Students in India
}

\author{
Sana Aslam \\ Research Scholar \\ Department of Library and Information Science \\ Babasaheb Bhimrao Ambedkar University \\ Lucknow-226025 \\ Email: sanaaslam13895@gmail.com \\ Sharad Kumar Sonkar \\ Associate Professor \\ Department of Library and Information Science \\ Babasaheb Bhimrao Ambedkar University \\ Lucknow-226025 \\ Email:sksonker@yahoo.co.in \\ \& \\ Valentine Joseph Owan \\ Research Fellow and Data Analyst \\ Department of Educational Management, Faculty of Education \\ University of Calabar, \\ Calabar-Nigeria \\ Email: owanvalentine@gmail.com
}

\begin{abstract}
With the rapid advancement of society, online learning has become more popular in the entire world due to Covid-19 pandemic. The pandemic offered almost a total paradigm shift to online teaching and learning across various educational platforms. This paper was aimed at reviewing the teaching and learning changes in higher education during COVID-19 Lockdown using empirical evidence from central universities in India. The study adopted a survey method utilizing an online questionnaire as the primary tool for data collection. The study covered 19 Central Universities in India that are offering Library and Information Science courses. Major findings showed, amongst others, that- most universities provided online classes during the lockdown period; Zoom application was the most utilized for online instructional during the COVID-19 Lockdown; the major difficulty faced by students during the online classes was the lack of internet facilities; the use of webinars in the field of LIS field was considered as an important source of education and learning. Based on these findings, key implications were discussed for the sustainability of LIS teaching and learning in higher education.
\end{abstract}

Keywords: Covid-19, higher education, India, LIS students, lockdown, online learning. 


\section{Introduction}

Covid-19 is an infectious disease caused by the corona-virus. The corona virus began in Wuhan, China, in December 2019. It is a massive group of infections which can cause fever, dry cough, and illness in human beings or animals (National Health Mission, n.d.).The pandemic touched most of the regions, with education being one of the most influential sectors to face the harsh effects of the virus, following various mitigation policies of the World Health Organisation (WHO). Students and educators lost a significant time for studies and instruction during the forced lockdown, amid the SARSCov2 pandemic across the world (Kannankara, 2020). Online teaching and learning technology played a major role in ensuring the continuity of academic activities in the same period. With the use of important technologies and the internet, online teaching and learning have been made possible through the development and deployment of various electronic resources.

The education system in almost all countries of the world was disturbed in the era of COVID-19 pandemic. Education has changed significantly, with the individual rise of online learning, whereby learning and teaching are embraced remotely on digital platforms (Li \& Lalani, 2020). Online learning is a type of distance learning or distance education, which has long been a part of the American education system, and has become the largest sector of distance learning in recent years (Bartley \& Golek, 2004; Evans \& Haase, 2001). Online learning is a type of training that is progressively being utilized for advanced education all over the world (Bartley \& Golek, 2004). According to Laurillard (2004), “online learning describes the interaction in which students use different types of ICTs in their learning processes. Education in a knowledge society context is given a key role in developing new ideas in learning and teaching through 
online learning." The covid-19 pandemic has extensively interrupted the higher education sector, where both staff and students in India are grossly affected, as they are made to stay at home.

The government has ordered a lockdown and asked the people to stay at their homes of the risk of this infection on human life. The central aim of the lockdown is to avoid the spread of infection from one person to another, to keep protecting ourselves as well as other people. This implies, not stepping out of the house except purchasing necessities. In this period, online learning is the best learning method for encouraging all students and completing the coursework (ET Government, 2020). Consequently, universities and colleges have started online teaching to the students. Online learning plays a vital role in the education field. In 1999 the first online learning was started at the CBT system (Raad \& Khan, 2020).By changing the human perspective and altering the conventional attitude, the role of education is a social change and society is much predictable. This study was designed to explore the concepts of change in teaching and learning in Indian universities during the COVID-19 crisis.

\section{Review of literature}

Various studies have been conducted in related areas of this study, especially with respect to the Covid-19 pandemic. For instance, Khan and Raheem (2020) conducted a study on the role of e-learning in COVID -19 crises. In this study, the concept and highlights of e-learning, the job of it in English language educating and features of e-learning. In another study, Bao (2020) examined online teaching in higher education and COVID-19. This paper was focused on the case of Peking University in China. The investigation finishes up with five high impact standards for online teaching. Allo (2020) examines a study to investigate the student's perception of online learning during a COVID-19 pandemic. In this study, the author applied a qualitative 
method. It indicated that student's perception of online learning is good but also marked the light on the accessibility of web access, online learning usage and financial issues. It suggested that the Voice Note will be successfully utilized when giving directions. It inferred that the material and guidance actualized by the teacher in the web-based learning were difficult to utilize. Aslam and Sonkar (2019) conducted a study on online learning regarding Swayam and e-PGPathshala. This study is based on online learning is computer-based learning tools that authorize us to user gains from anytime and anywhere. In this paper, the author discussed the content of Swayam, ePG Pathshala for learners and educators.

Furthermore, Guragain (2016) examines the study to make an online learning course utilizing one of the stages accessible in Helsinki Metropolia University of Applied Sciences. This study is divided into various sections i.e., overview of online learning, a case study of one company in India, cost benefits and setting up an online course in the open stage edX along with dental cleanliness students. The study found how to make an online course in Metropolia edX stage. Nguyen (2015) reported that the study examines the viability of online learning by sorting out and summing up the discoveries and difficulties of online learning into positive, negative, blended, and invalid discoveries. Gilbert (2015) conducted a study on web-based teaching and learning. This paper investigates whether secondary school students could profit by online courses and looks at the potential difficulties and weakness of the online coursework. This paper brings up issues about how to best help secondary school students to enroll in an online course.

Arkorful and Abaidoo (2014) opined under the study of using e-learning in teaching in tertiary institutions. In the higher education system teaching and learning is very important in using modern Information and communication technologies. It uncovers a few perspectives that individuals and organizations have shared comprehensively on the selection and reconciliation of 
e-learning advancements in training through studies and different perceptions. It takes a gander at the importance or meanings of e-learning as given by various analysts and the job that elearning plays in higher instructive organizations corresponding to educating and learning forms, and the favorable circumstances and drawbacks of its appropriation and realization. Stern (n.d.) conducted a study on online learning. It explored what the experience of online learning resembles for students and how it has changed the job of the educator. Holmstrom and Pitkanen (2012) examined the study to describe e-learning in higher education at UMSA. The data were collected from the observations and Qualitative semi-structured interviews that were used to identify 10 teachers' convictions about e-learning. The Technological Pedagogical Content Knowledge system was utilized for breaking down the observations and interviews. It was found that teachers' believed e-learning is helpful for themselves and their students.

\section{Objectives of the study}

$>$ To explored changes in teaching and learning in higher education of LIS students.

To know the students are attentive to join the classes during COVID-19 lockdown.

To identify how much time is spent during online classes.

To identify the technology and software used during COVID-19 period.

To know the usefulness of the webinar related to the subject field.

To investigate problems faced by the students during online classes.

\section{Methodology}

To find out the Change in Teaching and Learning in Higher Education during COVID-19 Lockdown, the descriptive survey method has been conducted. A structured online questionnaire as a tool for the data collection was designed with the help of Google forms and distributed to the 
UG and PG Students among all the Central Universities in India. There are 19 Central Universities in India which offer Library and Information Science courses. Data were collected from 17 Central Universities of India. A total of 282 copies of an electronic questionnaire were received as responses from students of 17 universities. Two universities did not respond (i.e., Mahatma Gandhi Central University, Motihari; Hemvanti Nandan Bahuguna Garhwal University, Uttrakhand). Data collection duration lasted from June to July 2020. Collected data were organized systematically using Microsoft Excel for simple arithmetic calculations, tabulations and graphs.

\section{Results}

\section{Respondent's demographic information}

The results of the analysis showed that, out of the 19 central universities in India which offer Library and Information Science Courses, respondents were distributed across only 17 universities. Most of the respondents are from the Babasaheb Bhimrao Ambedkar University 50(17.6\%), followed by Aligarh Muslim University 36(12.7\%), Dr Hari Singh Gour University 34(12\%), Banaras Hindu University 27(9.5\%), North Eastern Hill University 23(8.1\%), Tripura University 19(6.7\%), University of Delhi and Mizoram University 16(5.6\%), Central University of Himachal Pradesh 14(4.9\%), Central University of Haryana and Jamia Millia Islamia University 11(3.8\%), Central University of Tamil Nadu 7(2.4\%), Central University of Gujarat 5(1.7\%), Manipur University, Pondicherry University and Assam University 4(1.4\%), and Central University of Punjab $1(0.3 \%)$ in that order. However, none of the respondents is from Hemvanti Nandan Bahuguna Garhwal University and Mahatma Gandhi Central University. This information is illustrated graphically in figure 1. 
The result of the analysis of respondents' gender showed that most of the respondents were males $148(53 \%)$ and the least respondents were females $134(47 \%)$. In terms of educational qualification, it was shown that the majority of the respondents $190(67.4 \%)$ are PG students and the least respondents $92(32.6 \%)$ are UG students.

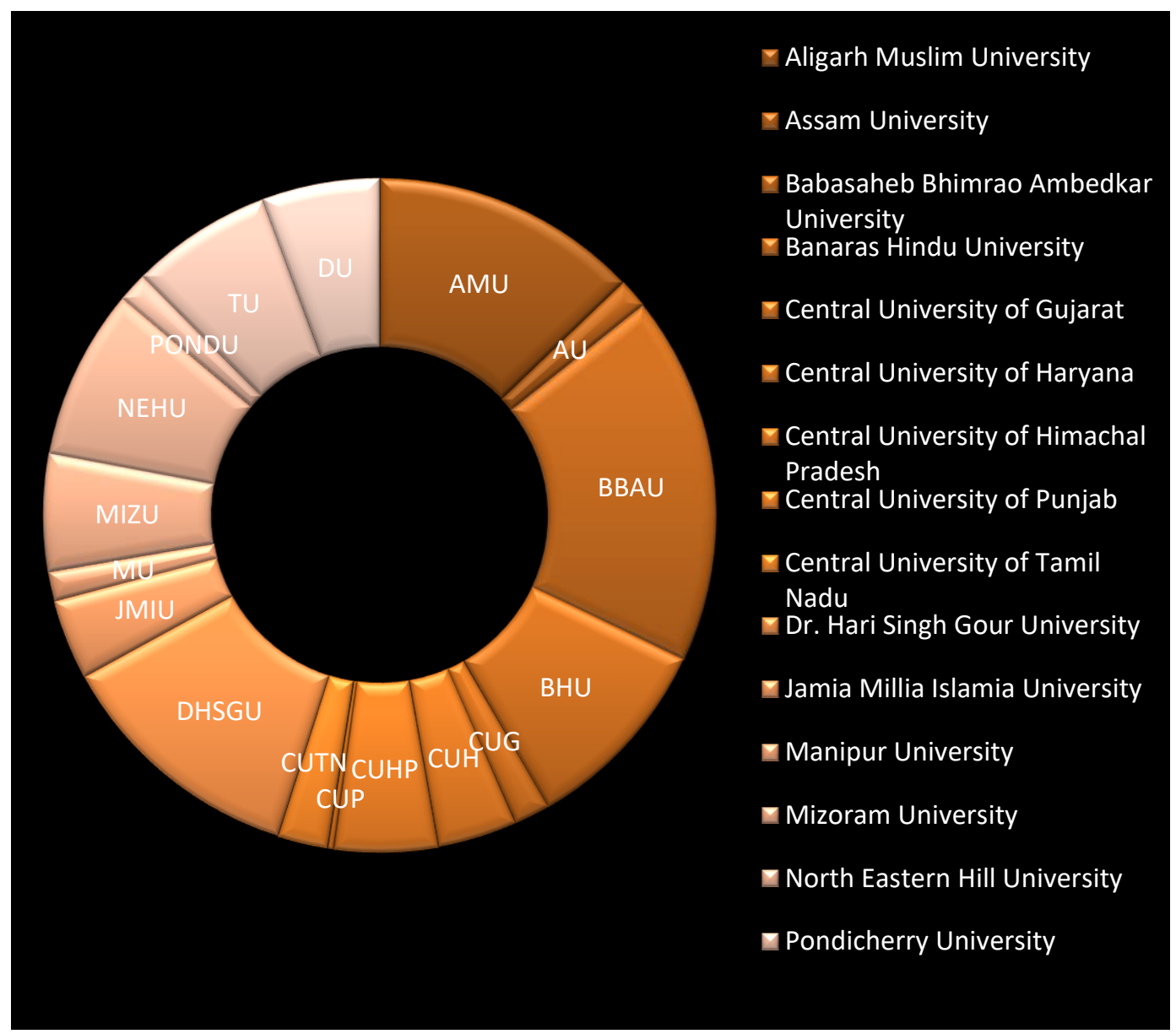

Fig. 1: LIS Central Universities in India whose students participated in the study

\section{Research question 1}

To what extent did Indian Central universities provide online learning during the Covid19 lockdown and what was the frequency of provision? The result of the analysis showed that most of the Central Universities $275(97 \%)$ provided online classes during the lockdown period 
and only $07(3 \%$ ) universities are not providing online classes (see Fig.2). It was also shown that $24.5 \%$ of the respondents indicated that they took online classes every day; this is followed by $33 \%$ of the respondents who indicated that they took online classes when required; $17.7 \%$ of the respondents took classes 2-3 times in a week; $20.9 \%$ respondents took classes 4-5 times in a week; only $1.4 \%$ of the respondents took classes $10-15$ days; while $2.5 \%$ of the respondents did not take any online classes (Fig. 3).

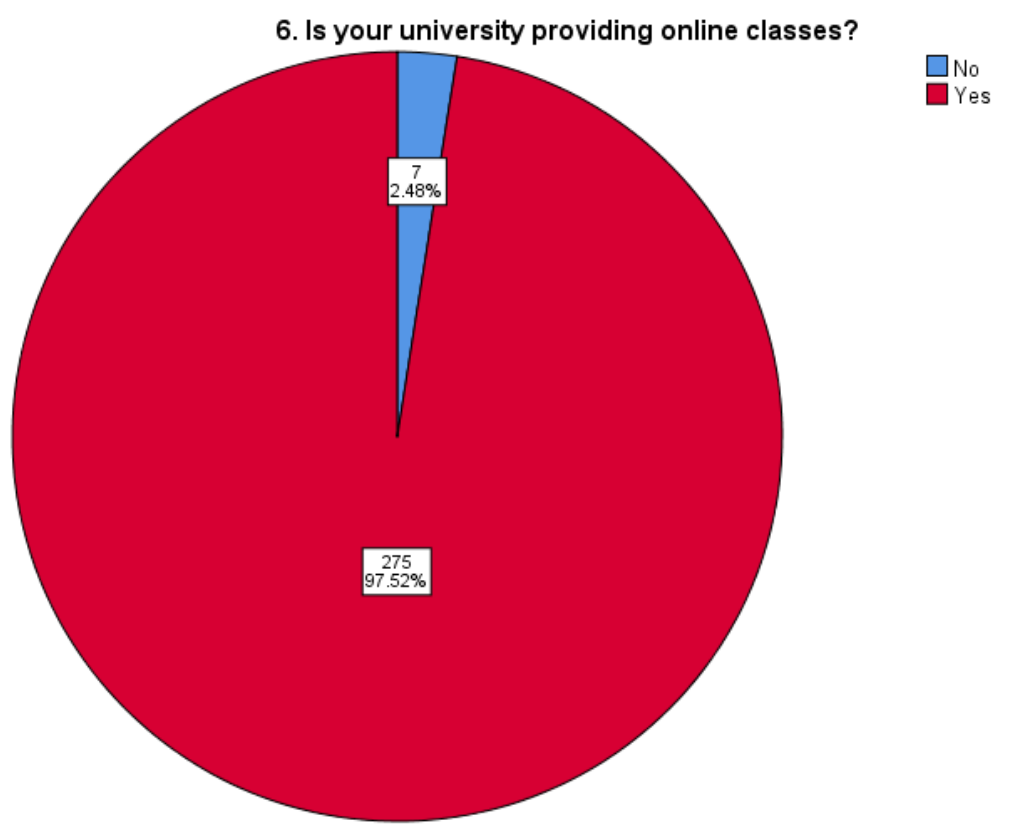

Fig. 2: Extent to which central universities are providing online classes 


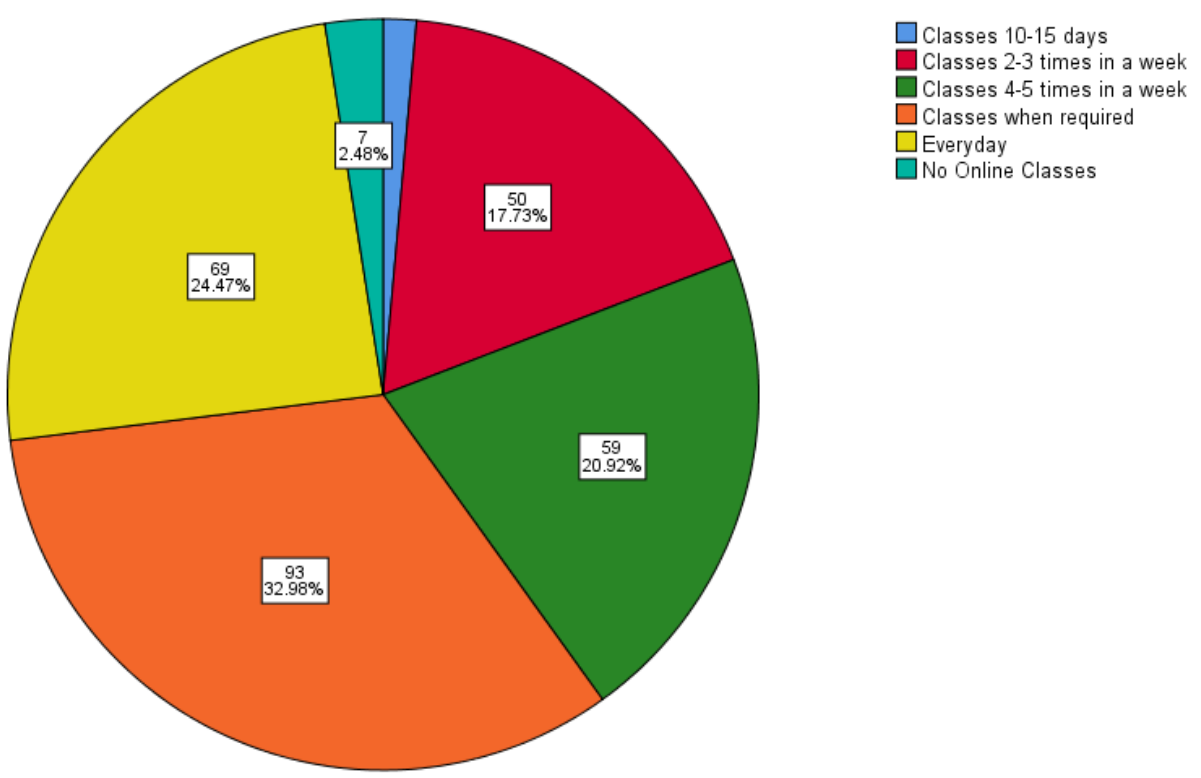

Fig. 3: Frequency of the provision of online classes during the Covid-19 lockdown Research question 2

How much time did students spend during online classes daily and what online services were provided during the lockdown? The results indicate that majority of the respondents $62.1 \%$ spent between 1-2 hours during online classes per day followed by $33.3 \%$ of the respondents who spent 2-3 hours, $3.9 \%$ of the respondents who spent $4-5$ hours and $0.7 \%$ of the respondents who spent 6-7 hours daily (see Fig. 4). In terms of the online services provided, the analysis revealed that most of the universities $(74.8 \%)$ provided online learning materials, followed by the conduction of online classes (69.9\%), video lecture (57.4\%), provision of access to e-books/ e-journals/ e-database (42.9\%), reference and Information service on request (17.7\%), support of research data service online $(15.9 \%)$, only virtual or telephonic guidance $(15.5 \%)$ and other services are (2.8\%). This information has been provided pictorially in Fig. 5. 


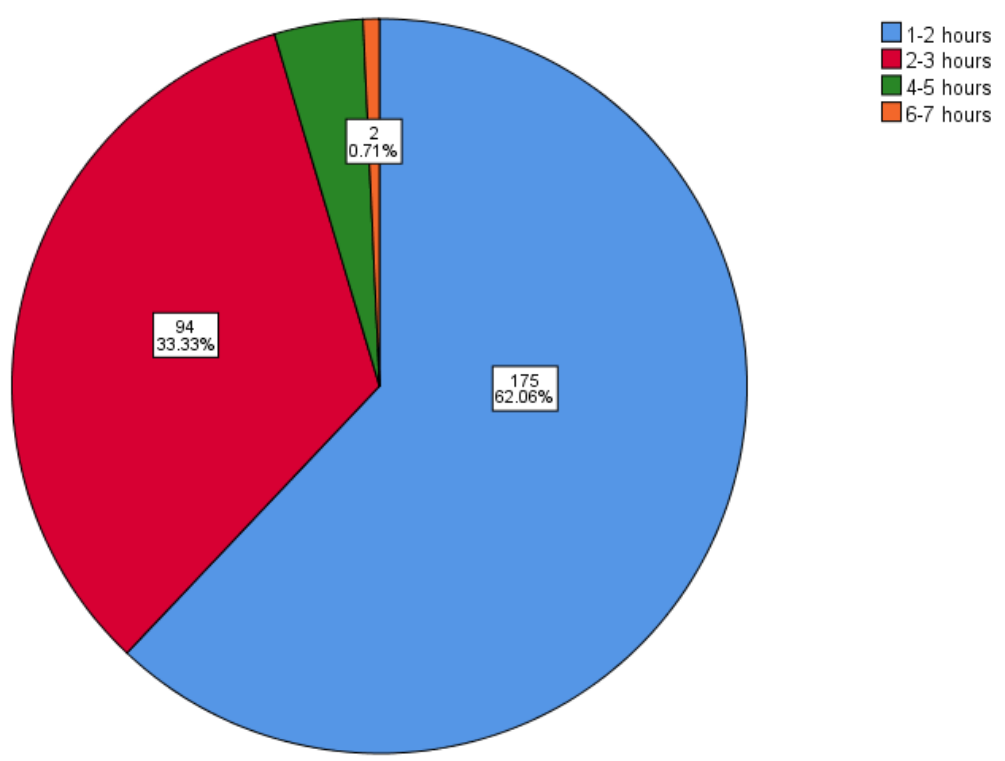

Fig. 4: Time students spent on online classes per day

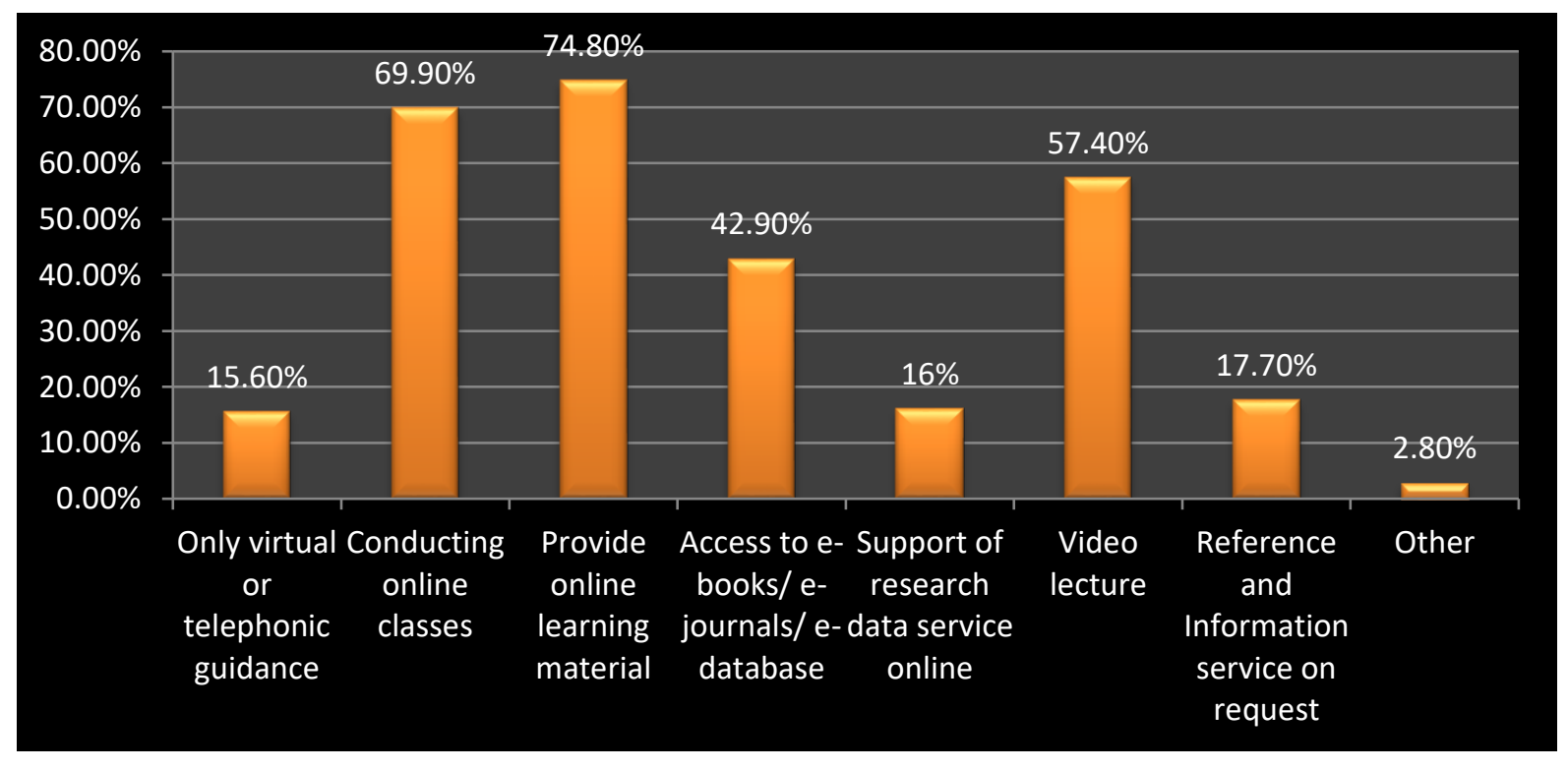

Fig. 5: Online services provided by central universities during the lockdown

\section{Research question 3}

To what extent did students grade the quality of the online instruction based on their perception and what were the most predominantly used devices for online classes? The results of the analysis indicate that majority of the respondents (37.6\%) graded the online lectures as being 
"Good" (41-60 marks on a scale of 100). This is followed by $31.6 \%$ and $21.6 \%$ of the respondents who perceived the online lectures as being "Very Good" (61-80 marks) and "Fair" (20-40 marks) respectively. However, only (9.2\%) of the respondents perceived the online lectures as being "Excellent" by awarding between 81-100 marks (see Fig 6). For the devices used for online classes, the analysis showed that most of the respondents (81.9\%) used mobile devices for online classes, followed by $17 \%$ of the respondents who used laptops, $0.7 \%$ who used tablets, and $0.4 \%$ of the respondents that made use of personal computers. Apart from these, none of the respondents used other devices (See Fig. 7).

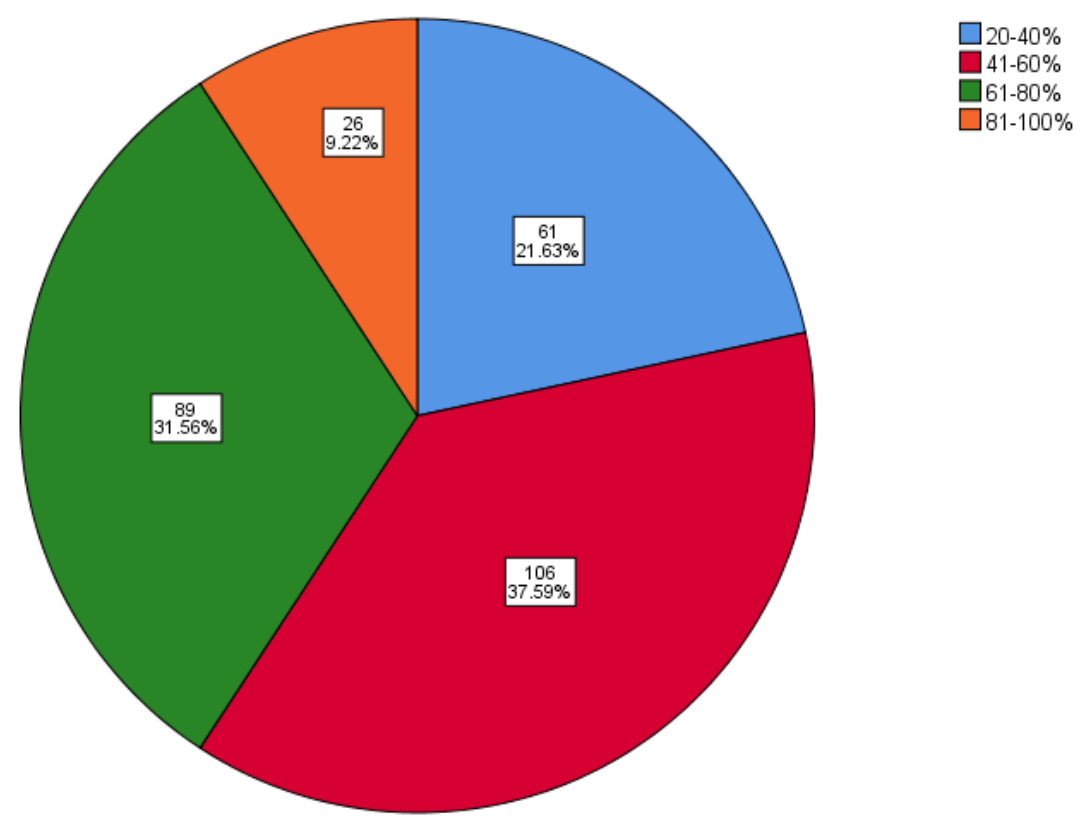

Fig. 6: Students' grading of the quality of online instruction based on their perception 


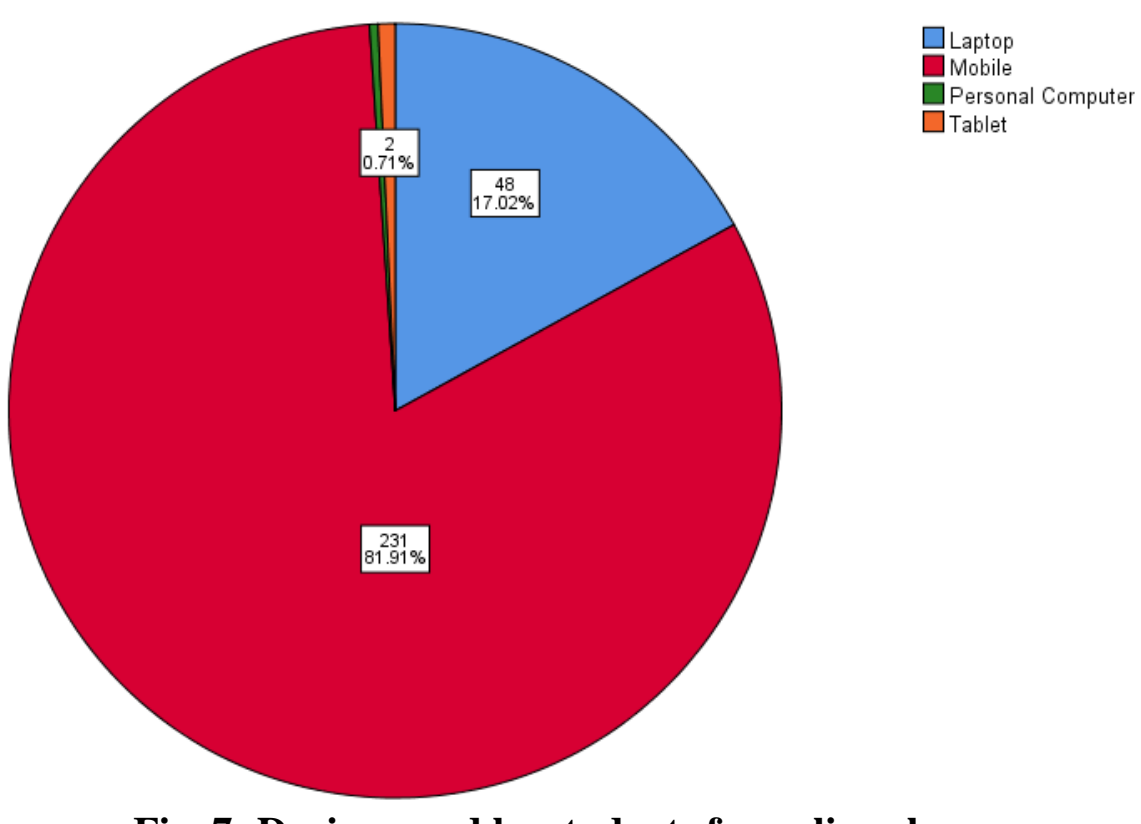

Fig. 7: Devices used by students for online classes

\section{Research question 4}

What were the online platforms used for content delivery, what specific software was deployed for online learning and what resources were used for teaching/learning during the lockdown? The results showed that majority of respondents $29.4 \%$ indicated that they received contents through WhatsApp, 29.4\% indicated that contents were received through online classes, $28 \%$ indicated that they received contents through email, 5.3\% indicated that they received contents through learning management system (LMS), 7.6\% indicated that they received lesson contents through other methods (such as department website, blogs, zoom applications). Only $0.7 \%$ of the respondents indicated that they received contents through YouTube, while none of the respondents received contents through any local channels. In terms of the specific software employed for the online classes, the results of the analysis depicted a clear picture that the ZOOM application was the most utilized (55.3\%) during this lockdown period. Trailing Zoom 
are other applications like skype, Google Classroom, Jitsi Meet etc (20.6\%), WebEx (11\%) Google Meet (10.3\%) and Webinar application (2.8\%) in that order. The results contained in Fig. 8 indicates that majority of the respondents (62.8\%) used e-PG Pathshala followed by eGyankosh (21.6\%), NDL (9.2\%), other resources (4.2\%), Springer Open Journal (1.4\%). Furthermore, only $1.4 \%$ of the respondents indicated that they used DOAJ and Taylor and Francis Journals respectively, while none of the respondents utilized the DOAB and Cambridge University Press resources.

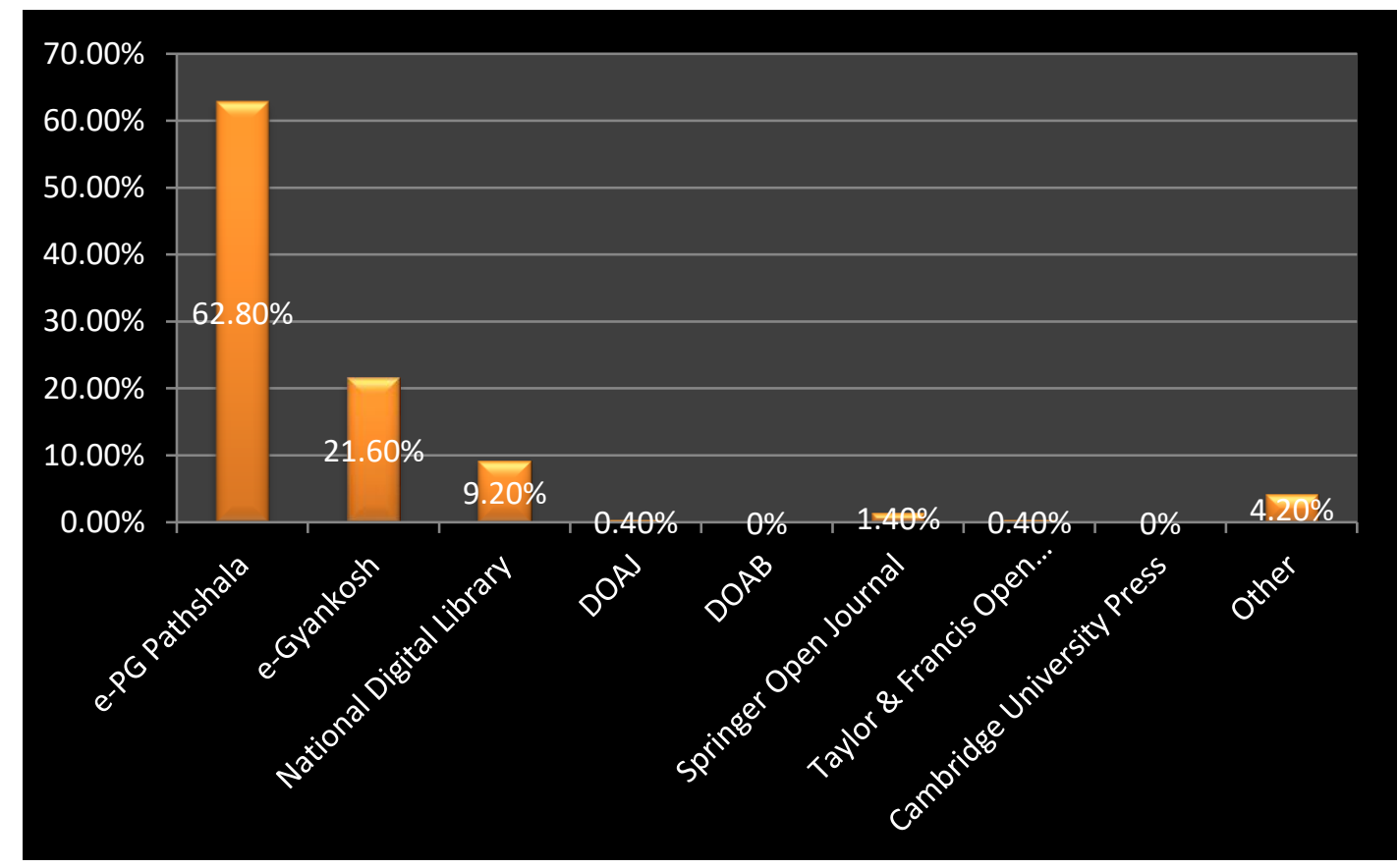

Figure 8: Resources used in teaching and learning

\section{Research question 5}

Who were the key facilitators of the online syllabus during the Covid-19 lockdown and to what extent are students satisfied with the online classes? The results of the analysis revealed that the online syllabus was facilitated mostly by teachers $(63.8 \%)$, followed by students themselves (31.6\%), then by others (3.5), through the help of a friend (1.1\%) and lastly through 
the support of a family member $(0.4 \%)$. In terms of the extent of students' satisfaction with the online classes, the results of the analysis depicted in Fig. 9 shows that $3.9 \%$ of the respondents were highly satisfied, $42.9 \%$ were satisfied, $37.6 \%$ were neutral, $2.1 \%$ were highly dissatisfied, while $13.5 \%$ were dissatisfied.

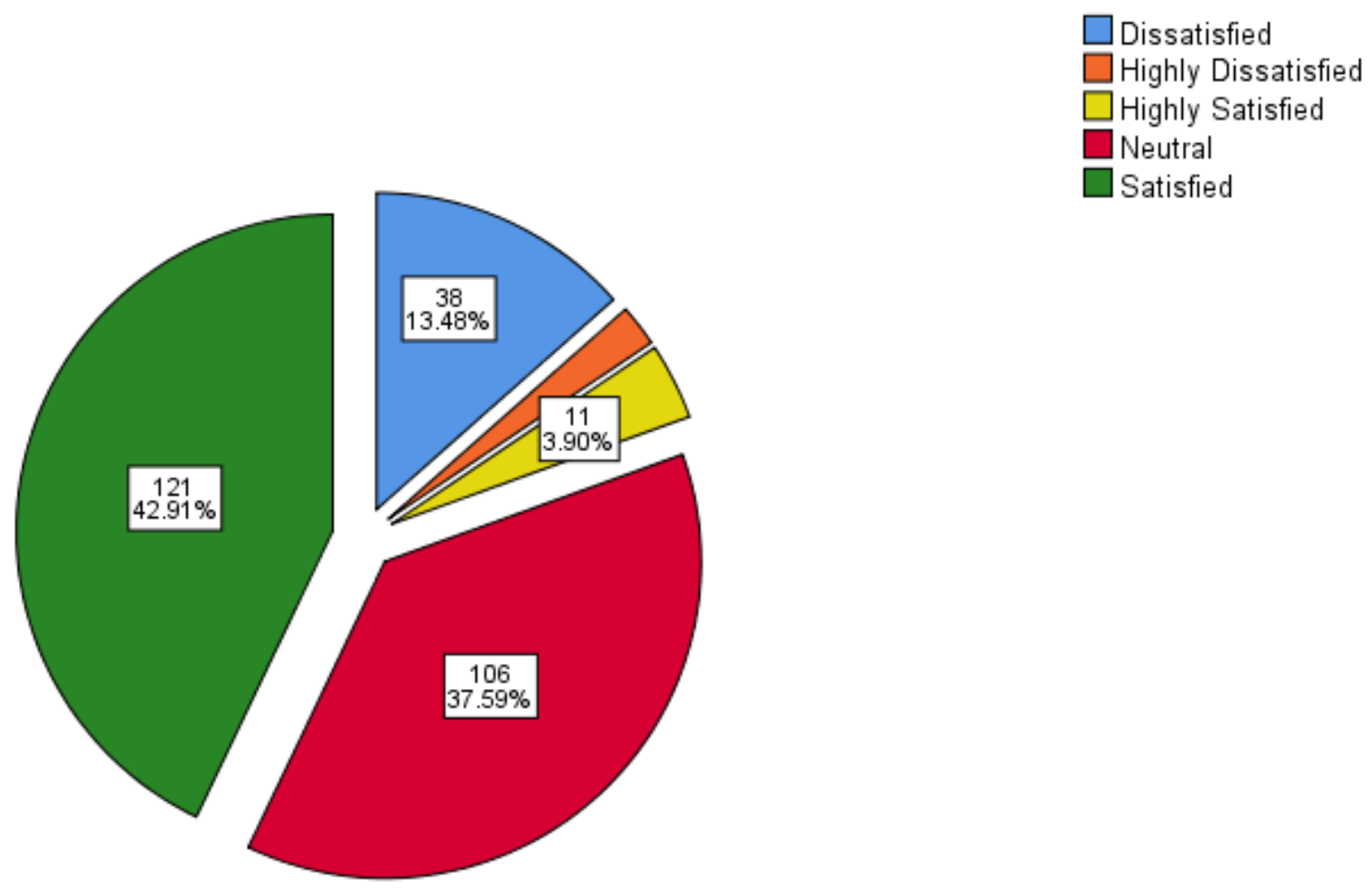

Fig 9: The extent of students' satisfaction with online classes

\section{Research question 6}

What are the difficulties faced during the online classes? It was revealed through the results in Table 1 that the most problem faced during online classes include lack of internet facilities (76.6\%), background noise (34.4\%), charging problem in devices $(23 \%)$, lack of devices (18.4\%), Lack of ICT skills (13.1\%), insufficient time by students (10.3\%), teachers do not take classed at the convenience of students $(8.2 \%)$, and other unspecified reasons $(7.2 \%)$. 
Table 1: Difficulties faced during online classes

\begin{tabular}{llcc}
\hline S/N & \multicolumn{1}{c}{ Difficulty Faced } & Response & Percentage \\
\hline 1. & Background noise & 97 & $34.4 \%$ \\
2. & Don't have time & 29 & $10.3 \%$ \\
3. & Lack of Internet facilities & 216 & $76.6 \%$ \\
4. & Lack of ICT skills & 37 & $13.1 \%$ \\
5. & Lack of devices & 52 & $18.4 \%$ \\
6. & Charging problem in devices & 65 & $23 \%$ \\
7. & Teachers do not take classes at students' convenience & 23 & $8.2 \%$ \\
8. & Other factors & 18 & $7.2 \%$ \\
\hline
\end{tabular}

\section{Research question 7}

To what extent did students attend webinars related to the subject field during the lockdown, from which sources did students get to know about such webinars and what is their opinion regarding the usefulness of the webinars? Regarding these questions, the result of the analysis revealed that most of the respondents $(57.4 \%)$ indicated that they did not attend any webinar related to the subject field during the lockdown period while $42.6 \%$ of the respondents 
indicated that they attended webinars during the lockdown period. From the respondents who indicated that they attended webinars, it was revealed that most $52.8 \%$ knew about the webinars through their teachers, $20.6 \%$ knew about the webinars through their friends, $18.1 \%$ knew through the LIS forum, 5.7\% through Facebook and 2.8\% through other sources. In terms of respondents' opinions on the usefulness of the webinars, the analysis showed clearly that most of the respondents $(65.2 \%)$ attended webinars to update their knowledge, $20.9 \%$ attended webinars because it helps them to study, $8.5 \%$ attended webinars as a means of engaging their free time, $2.5 \%$ attended webinars because it was helpful to enable them to pass competitive exams, while $2.6 \%$ attended webinars for other unspecified reasons.

\section{Research question 8}

To what extent did students increase their IT skills during the lockdown and what is the opinion of LIS students regarding the superiority of class teaching over online teaching? The results of the analysis showed that $76.2 \%$ of respondents increased their IT skills during the COVID-19 lockdown period while $23.8 \%$ of respondents did not. In terms of class teaching versus online teaching, the results indicated that $41.5 \%$ of the respondents strongly agreed that class teaching is better than online teaching, $28.7 \%$ also agreed. However, $14.9 \%$ of the respondents were neutral, $10.6 \%$ of the respondents disagreed while $4.3 \%$ of the respondents strongly disagreed in favour of online teaching (See Fig. 10). 


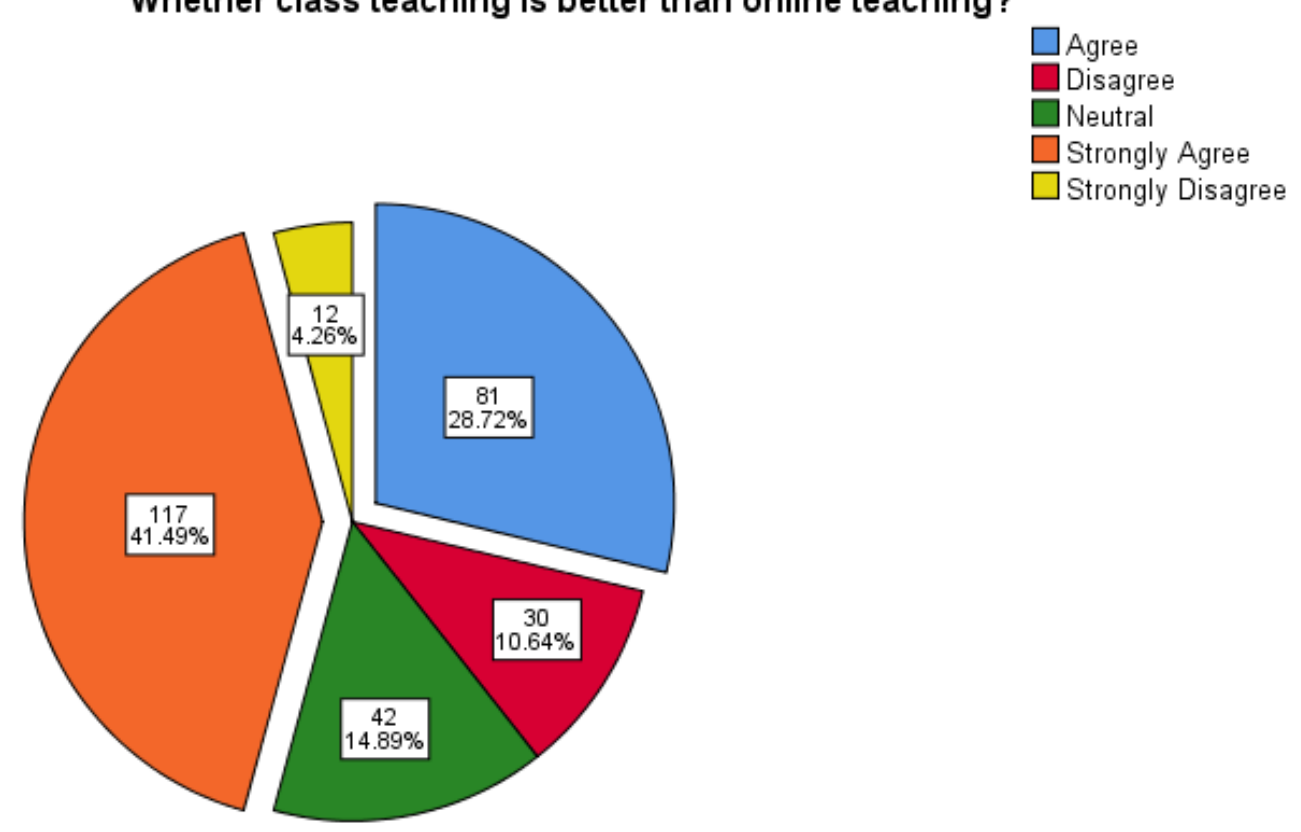

Fig. 10: Students' preference for class teaching versus online teaching

\section{Discussion of findings}

The first finding of this study depicted that many central universities in India provided online classes during the Covid-19-imposed lockdown. This finding is not surprising considering that educational institutions were restricted from operating fully as a means of mitigating the spread of the virus. Considering the public advocacy for a switch to electronic learning during the peak of the pandemic (Bao, 2020; Basilaia \& Kvavadze, 2020; Toquero, 2020), it is well justified that most universities in India were not left behind in following global best practices, hence the finding of this study.

This study also showed that most students utilized mobile devices for online classes than tablets and laptops; while none of the students used PC and other devices. This finding may be attributed to the wide and varied possession of mobile and portable gadgets such as mobile phones, tablets and laptops. Again, these portable devices are usually powered by an internal battery functionality that enables them to be fully operational with little or no electricity. This 
advantage makes the use of battery-characterized devices in the home to be very reasonable and flexible. Most PCs and other electric-based devices were not widely used perhaps due to power problems, their bulky nature, and the need for extraneous peripheral devices to be connected (making them non-portable and space-consuming).

The third major finding of this study revealed that learning contents were predominantly received through online classes and the platform for content reception was majorly through WhatsApp, with the least being the Learning Management Systems. This finding may be attributed to the steady availability of the WhatsApp platform on students' portable devices such as mobile phones, tablets and/or laptops. Learning Management Systems may have received the least utility because the administrative access of such platforms is not students-dependent. Thus, the closure of higher education institutions may have limited students' access to such institutionbased platforms.

This study revealed that the Zoom application was the most utilized during this lockdown period. The position of this finding in not negligible but quite interesting because the Zoom application is supported by handheld devices such as smart phones and tablets, as well as other devices such as laptops and PCs. The wide support across various devices offers it a wide scope of receptibility, making it the most used. Apart from these, the Zoom application is well designed with suitability to support a meeting involving a large number of participants. The features of the Zoom application are user-friendly with its cloud-based recording functionality offering superb access to meeting proceedings for future purposes. All these and many more could be the reasons why the Zoom application seems to be the leader among electronic or video conferencing applications across the world today. 
The limitations of the study which are- The study is limited within India. Two universities have not responded i.e. Mahatma Gandhi Central University (Motihari) and Hemvanti Nandan Bahuguna Garhwal University (Uttrakhand) due to some reasons. There are numbers of Universities in India, only covered Central Universities in India because it has a wide range of usage of Online learning during COVID-19 Lockdown in all over India.

\section{Conclusion}

To slow the spread of COVID-19, one of the major steps is staying at home. These days technology is more useful in our daily life. Thus, all the universities, institutions/colleges have been closed in India and all over the world. During the period of COVID-19 pandemic, in the teaching and learning process internet, online learning, computers/laptop have been essentially used. This study proved that mostly Central Universities are providing online classes during the lockdown period and using applications like Zoom, WebEx, Google Meet etc have been helping the students to learn at home in this pandemic period. It also proved that students are satisfied with the online classes. Online learning provides an opportunity to enhance skills and importance in self-development. Contribution of effort is resisting the lack of knowledge. We all know that due to lockdown there is a concept emerging which is "Work from Home." It is a better medium for learning and plays a vital role in epidemic situations.

\section{References}

Allo, M. D. (2020). Is online learning good in the midst of Covid-19 Pandemic. The case of EFL learners. Jurnal Sinestesia, 10(1), 1-10.

Arkorful, V. \& Abaidoo, (2014). N. The role of e-learning, the advantages and disadvantages of its adoption in Higher Education. International Journal of Education and Research, 2(12), 1-14. 
Aslam, S. \& Sonkar, S. K. (2019). Online Learning with Special Reference to SWAYAM and e-PG Pathshala: An Overview. New Delhi: Pinnacle Learning. ISBN: 978-93-83848$52-2$.

Bao, W. (2020). COVID-19 and online teaching in higher education: A case study of Peking University. Human Behavior and Emerging Technologies, March, 113-115. https://doi.org/10.1002/hbe2.191

Bartley, S. J. \& Golek, J. H. (2004). Evaluating the Cost-Effectiveness of Online and Faceto-Face Instruction. Educational Technology \& Society, 7(4), 167-175.

Basilaia, G., \& Kvavadze, D. (2020). Transition to Online Education in Schools during a SARS-CoV-2 Coronavirus (COVID-19) Pandemic in Georgia. Pedagogical Research, 5(4). https://doi.org/10.29333/pr/7937

Casares, J. (2011). The Future of Teaching and Learning in Higher Education.

Dhawan, S. (2020). Online Learning: A Panacea in the Time of COVID-19 Crisis. Journal of Educational Technology Systems, April 2020.https://doi.org/10.1177/0047239520934018 (Accessed on 15 April 2020)

Elsalem, L., Al-Azzam, N., Jum'ah, A.A., Obeidat, N., Sindiani, A.M. \&Kheirallah, K.A. (2020). Stress and behavioral changes with remote E-exams during the Covid-19 pandemic: A cross-sectional study among undergraduates of medical sciences. Annals of Medicine and Surgery.

ETGovernment. (2020). COVID-19 Pandemic: Impact and strategies for education sector in India. https://government.economictimes.indiatimes.com/news/education/covid-19pandemic-impact-and-strategies-for-education-sector-in-india/75173099 (Accessed on 16 April 2020)

Evans, J. \& Haase, I. (2001). Online business education in the twenty-first century: an analysis of potential target markets. Internet Research, 2001, 11(3), 246-260. http://doi.org/10.1108/10662240110396432 (Accessed on 2001)

Fatima, N. \& K S.A. (2019). E-learning Research Papers in Web of Science: A Bibliometric Analysis. Library Philosophy and Practice (e-journal), 2144.

Gilbert, B. (2015). Online Learning Revealing the Benefits and Challenges. Library Philosophy and Practice (e-journal). Education Masters, 303.

Glasby, P. (2015). Future Trends in Teaching and Learning in Higher Education, Institute for Teaching and Learning Innovation. 
Guragain, N. (2016). E-Learning Benefits and Applications. Helsinki Metropolia University of Applied Sciences. Information Technology.

Holmstrom, T. \& Pitkanen, J. (2012). E-learning in higher education. Umea University: Department of Education.

Islam, M.A., Barna, S.D., Raihan, H., Khan, M.N.A. \& Hossain, M.T. (2020). Depression and anxiety among university students during the COVID-19 pandemic in Bangladesh: A web-based cross-sectional survey. PloS one, 15(8), e0238162.

Kannankara, A. (2020). E- learning: The Best Bet during lockdown. https://english.mathrubhumi.com/features/specials/e-learning-the-best-bet-duringlockdown--1.4730381 (Accessed on 2 May 2020)

Laurillard, D. (2004). E-Learning in Higher Education. Changing Higher Education, 1-13.

Li, C. \& Lalani, F. (2020). The COVID-19 pandemic has changed education forever. https://www.weforum.org/agenda/2020/04/coronavirus-education-global-covid19-onlinedigital-learning/ (Accessed on 29 April 2020)

Murgatrotd, S. (2020). COVID-19 and Online Learning. Strategic foresight for Educational Leaders. DOI: 10.13140/RG.2.2.31132.85120

Nash, J. A. (2015). Future of Online Education in Crisis: A Call to Action. Turkish Online Journal of Educational Technology-TOJET, 14(2), 80-88.

National Health Mission. (n.d.). Detail Question and Answers on COVID-19 for Public. https://www.mohfw.gov.in/pdf/FAQ.pdf (Accessed on n.d.)

(n.d.). Minding our minds during the COVID-19. https://www.mohfw.gov.in/pdf/MindingourmindsduringCoronaeditedat.pdf (Accessed on n.d.)

Nguyen, T. (2015). The Effectiveness of Online Learning: Beyond No Significant Difference and Future Horizons. MERLOT Journal of Online Learning and Teaching, 11(2).

Nnebedum, C., Obuegbe, A.S. \& Nwafor, H.E. (2020). Assessment of schools' reopening after COVID-19 closures. International Journal on Studies in Education, 3(2), 86-91.

Oassim-Al-shboul, O.M. Sabiote, C.R.\& Álvarez-Rodríguez, J. (2015). Professors' perceptions of distance education in virtual environments: The case of the Education Faculty of University of Al-Yarmouk (Jordan). Digital Education Review, (28), 142-162. 
Obanya, P., Shabani, J. \& Okebukola, P. (n.d.). Guide to Teaching and Learning in Higher Education. Unesco, (Accessed on n.d.)

Raad, B. \& Khan, M. A. (2020). The Role of E-Learning in Covid-19 Crisis. International Journal of Creative Research Thoughts, 8(3), 3135-3138.

Radu, M. C., Schnakovszky, C., Herghelegiu, E., Ciubotariu, V.A. \& Cristea, I. (2020). The Impact of the COVID-19 Pandemic on the Quality of Educational Process: A Student Survey. International Journal of Environmental Research and Public Health, 17(21), 7770 .

Stern, J. (n.d.). Introduction to Online Teaching and Learning. http://www.sloanc.org/resources/index.asp (Accessed on n.d.)

Toquero, C. M. (2020). Challenges-and-Opportunities-for-Higher-Education-Amid-theCovid-19-Pandemic-the-Philippine-Context. Pedagogical Research, 5(4), em0063. https://doi.org/10.29333/pr/7947

You, J. W. \& Kang, M. (2014). The role of academic emotions in the relationship between perceived academic control and self-regulated learning in online learning. Computers \& Education, 77, 125-133. 